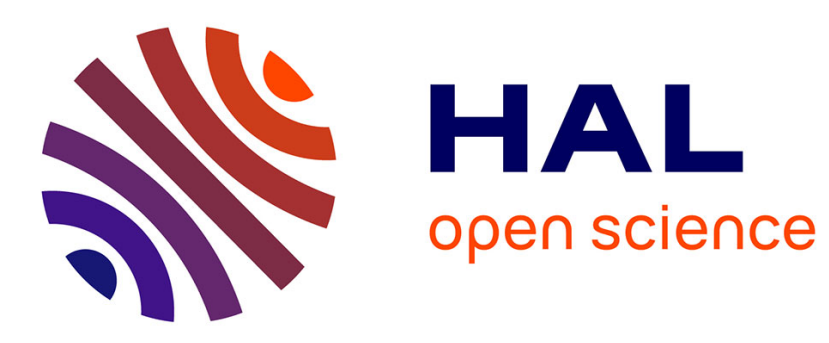

\title{
Degradation of alloxydim in chlorinated water
}

Pilar Sandín-España, Inés Santín, José Oriol Magrans, José Luis

Alonso-Prados, José María García-Baudín

\section{To cite this version:}

Pilar Sandín-España, Inés Santín, José Oriol Magrans, José Luis Alonso-Prados, José María GarcíaBaudín. Degradation of alloxydim in chlorinated water. Agronomy for Sustainable Development, 2005, 25 (2), pp.331-334. hal-00886269

\section{HAL Id: hal-00886269 \\ https://hal.science/hal-00886269}

Submitted on 1 Jan 2005

HAL is a multi-disciplinary open access archive for the deposit and dissemination of scientific research documents, whether they are published or not. The documents may come from teaching and research institutions in France or abroad, or from public or private research centers.
L'archive ouverte pluridisciplinaire HAL, est destinée au dépôt et à la diffusion de documents scientifiques de niveau recherche, publiés ou non, émanant des établissements d'enseignement et de recherche français ou étrangers, des laboratoires publics ou privés. 


\title{
Degradation of alloxydim in chlorinated water
}

\author{
Pilar SANDín-ESPAÑA, Inés SANTín, José Oriol MAGRANS, José Luis ALONSO-PRADOS, \\ José María GARCÍA-BAUDíN* \\ Departamento de Protección Vegetal, Instituto Nacional de Investigación y Tecnología Agraria y Alimentaria (INIA), \\ Ctra. de la Coruña, Km 7.5, 28040 Madrid, Spain
}

(Accepted 17 January 2005)

\begin{abstract}
One of the most common disinfectant agents used for water disinfection, sodium hypochlorite, was employed to investigate the degradation of the herbicide alloxydim. The half-life of alloxydim in the presence of a chlorine excess was determined to be $\mathrm{DT}_{50}<30 \mathrm{~s}$. Degradation of alloxydim in chlorinated water gave rise to a main chlorinated by-product identified by using liquid chromatography (LC) coupled with mass spectrometry (MS). This by-product was produced from the parent compound in amounts that allowed the study of its phytotoxicity on wheat. Bioassays showed that the metabolite had an effect on the root growth with doses from $0.1 \mathrm{mg} \cdot \mathrm{L}^{-1}$.
\end{abstract}

by-product / chlorination / bioassay / phytotoxicity / degradation

\section{INTRODUCTION}

Chlorine is one of the most common disinfectant agents employed in water treatment to control pathogenic bacteria. However, water chlorination may lead to the formation of a wide variety of undesirable by-products. In many cases, degradation by-products have not been identified and may be less or more toxic than their parent compound (Reckhow and Singer, 1990). For this reason, the identification and study of these by-products in pesticides assumes a determinant importance.

In order to achieve adequate control of herbicides in drinking water, it is necessary to know details of their behavior, not only in water sources but also in the water purification process. Whereas the degradation of many pesticides in chlorinated water has been widely studied (Magara et al., 1994), degradation of cyclohexanedione herbicides has been scarcely investigated. Cyclohexanedione herbicides (CHD, "dims") inhibit the activity of acetyl-Co A carboxilase, a crucial enzyme in fatty acid biosynthesis (Lichtenthaler, 1990). These herbicides are applied at relatively low doses of $0.2-0.5 \mathrm{~kg}$ a.i./ha (Maier et al., 1994). A published method for the analysis of different herbicides showed the difficulties in obtaining good recoveries when tap water was fortified with sethoxydim (Hu et al., 1999). This could be an indication of degradation of these kinds of substances in this matrix. In a previous work of our group, the rapid degradation suffered by the herbicide tepraloxydim in chlorinated water was observed (Sandín-España et al., 2002). However, studies on the degradation pathway of cyclohexanedione herbicides in chlorinated water are not found in the literature.
Alloxydim is a cyclohexanedione herbicide developed by BASF against grass weeds and volunteer cereals in sugar beet, vegetables and broad-leaved crops. In this work, a study of the reaction of alloxydim in the presence of aqueous hypochlorite was undertaken. High pressure liquid chromatography (HPLC)-ultraviolet (UV) was used to observe the variation of alloxydim concentration with time and to obtain kinetic information on the process. Once the degradation was completed, identification of the main metabolite was performed by high pressure liquid chromatography (HPLC)-electrospray ionization (ESI)-mass spectrometry (MS). This metabolite was isolated from the water phase using solid phase extraction (SPE) in order to obtain a pure compound that allowed the development of a bioassay to study its phytotoxicity. Bioassays are useful tools to screen herbicide phytotoxicity residues in soil. Bioassays to detect several herbicides have been reported in the literature, specially to detect low rate herbicides (HernándezSevillano et al., 2001; Horowitz, 1976).

A comparative study of the phytotoxicity of alloxydim and alloxydim metabolite with hydroponic bioassays on wheat was done.

\section{MATERIALS AND METHODS}

\subsection{Kinetic experiments, metabolite identification and isolation}

Alloxydim (98\% purity) was obtained from Dr. Ehrenstorfer (Augsburg, Germany). Stock solutions were prepared in HPLC water and stored at $4{ }^{\circ} \mathrm{C}$ in the dark. These solutions were used

\footnotetext{
* Corresponding author: baudin@inia.es
} 
to prepare more dilute standard solutions. The stability of standard solutions under these conditions was checked and demonstrated for at least two months.

HPLC/UV with a UV detector (200 to $290 \mathrm{~nm}$ ) and a NovaPak C18 column $(150 \times 3.9 \mathrm{~mm}, 60 \AA, 4 \mu \mathrm{m})$ was used to measure alloxydim concentrations in the kinetic experiments. Hypochlorite water solutions were prepared in terms of $\mathrm{Cl}_{2}$. All reactions investigated were carried out under controlled experimental conditions ( $\mathrm{pH}=9$ for reaction with hypochlorite, $25 \pm 2{ }^{\circ} \mathrm{C}$ ).

The reaction between alloxydim and disinfectant was studied using a disinfectant to herbicide ratio of 10:1 ( $\mathrm{mol} / \mathrm{mol})$. Excess of disinfectant represents a realistic worst case for a low dose herbicide such as alloxydim and ensures pseudo firstorder kinetic conditions, since the concentration of chlorine may be considered constant throughout the degradation experiment. The reaction was quenched with sodium thiosulfate at scheduled time intervals.

Blank samples containing only alloxydim were controlled to ensure that no photo-degradation or hydrolysis occurred during the experiment, and control samples without the addition of sodium thiosulfate were controlled at different intervals of the process to ensure no effect on by-products.

Sample aliquots of $50 \mu \mathrm{L}$ were injected into the HPLC/UV system. The mobile phase used was acetonitrile:water $(3: 2 \mathrm{v} /$ $\mathrm{v} ; 0.1 \%$ formic acid) with a flow rate of $1 \mathrm{~mL} \cdot \mathrm{min}^{-1}$. The detector was set at the maximum absorbance wavelength of alloxy$\operatorname{dim}(265 \mathrm{~nm})$. Under these conditions, the retention time of alloxydim was $4.2 \mathrm{~min}$. Concentrations of alloxydim were determined by measuring peak areas and compared with a calibration curve $\left(n=5, r^{2}=0.999\right)$. The main chlorinated by-product has a retention time of $5.4 \mathrm{~min}$.

HPLC/ESI/MS was used to identify and characterize degradation and reaction products. Samples from different time points in the degradation experiments were selected for HPLC/ MS analysis in order to identify the main degradation or reaction product.

The HPLC instrument was a Hewlett-Packard HP 1100MSD with a mass detector with quadrupole analyzer. A Zorbax C18 column $(5 \mathrm{~cm} \times 2 \mathrm{~mm} \times 5 \mu \mathrm{m})$ was employed for chromatographic separation.

Chromatographic conditions were as follows; mobile phase acetonitrile:water $(3: 2, \mathrm{v} / \mathrm{v} ; 0.1 \%$ formic acid) was used to characterize peaks previously identified by HPLC/UV analysis; flow rate was set to $0.2 \mathrm{~mL} \cdot \mathrm{min}^{-1}$; sample injection volume was $20 \mu \mathrm{L}$. Electrospray conditions were set as follows: drying gas flow (nitrogen) $10 \mathrm{~mL} \cdot \mathrm{min}^{-1}$; drying gas temperature $335^{\circ} \mathrm{C}$; nebulizer pressure $50 \mathrm{psi}$; capillary voltage $4000 \mathrm{~V}$. The ESI/ MS spectrometer was operated in the positive ion mode. Mass spectrometer conditions were optimized by ramping the fragmentor value, obtaining a maximum ionic efficiency of molecular ion of $100 \mathrm{~V}$. MS chromatograms were obtained with a mass range of 50 and $2000 \mathrm{amu}$ and a scan rate of 1.65 s/cycle.

A twelve-port Visiprep SPE vacuum manifold was used for SPE. Extraction and isolation was performed with an ISOLUTE ENV+ disposable cartridge packed with hyper crosslinked, styrene-divinylbenzene copolymer (500 mg, $3 \mathrm{~mL})$. A solution of 12.37 mmoles $(50 \mathrm{~mL})$ of hypochlorite was added to 1.24 mmoles $(50 \mathrm{~mL})$ of alloxydim. The reaction was stirred for 10 minutes and then quenched with $10 \mathrm{~mL}, 100$ mmoles of sodium thiosulfate. Then, the stirred mixture was passed through the cartridge at $5 \mathrm{~mL} \cdot \mathrm{min}^{-1}$ under vacuum. Thereafter, the solid phase was washed with $10 \mathrm{~mL}$ HPLC water and vacuum air-dried. Extraction was performed under gravity. Optimal elution volume was $5 \times 2 \mathrm{~mL}$ of $\mathrm{CH}_{2} \mathrm{Cl}_{2}$. The eluate was evaporated to dryness under an air stream.

\subsection{Hydroponic bioassays}

A hydroponic bioassay has been successfully used for comparing the phytotoxicity on wheat plants of alloxydim and the chlorinated metabolite. This procedure can detect phytotoxicity at very low concentrations of the chemical products.

Seeds were germinated for $48 \mathrm{~h}$ in Petri dishes on filter paper discs soaked in deionized water for two days and were placed on a plastic grid inside plastic glasses. The nutritive solution was based on Hewitt nutritive solution at $\mathrm{pH}=7$ (Hewitt and Bould, 1963). The doses assayed with alloxydim were 0.1 to $1 \mathrm{mg} \cdot \mathrm{L}^{-1}$, and with metabolite were from 0.1 to $10 \mathrm{mg} \cdot \mathrm{L}^{-1}$. Plants were watered every two days at the base of each plant. Controls with nutritive solution were included in each assay. The water used in the bioassays was mineral water to avoid the effect of chlorine on alloxydim degradation.

Wheat plants (Triticum aestivum cv. Marius) were grown under controlled conditions in a growth chamber $(16 \mathrm{~h}$ photoperiod, with an irradiation flux of $110-115 \mu \mathrm{E} \mathrm{m}^{-2} \mathrm{~s}^{-1}, 22 / 16^{\circ} \mathrm{C} \pm 1^{\circ} \mathrm{C}$ day/night temperatures and $70 \%$ relative humidity).

The experiment was designed as a randomized complete block with five replications for each concentration and five seeds per glass. Root growth was measured seven days after treatments. Root growth has been described as one of the most sensitive parameters for measuring herbicide phytotoxicity (Hernández-Sevillano et al., 2001). One-way analyses of variance (ANOVA) were conducted to determine differences between treatments, at the 0.05 significance level. Means were compared by the Newman-Keuls multiple range test at a significance level of $95 \%(P<0.05)$. The results were analyzed using a statistical procedure (StatGraphics Plus $4 \cdot 1^{\circledR}$ ).

\section{RESULTS AND DISCUSSION}

\subsection{Alloxydim degradation. Identification and isolation of a degradation by-product}

The initial mass concentration of alloxydim was $5 \mathrm{mg} \cdot \mathrm{L}^{-1}$ $(0.0154 \mathrm{mM})$. This concentration was selected to ensure the identification of all main metabolites produced during degradation. Alloxydim degrades very fast with hypochlorite. Nonlinear regression of data points to simple first-order kinetics allowed the estimation of its degradation half-life $\left(t_{1 / 2}=20 \mathrm{~s}\right.$, $\left.r^{2}=0.996\right)$. During the degradation experiment, the disappearance of alloxydim and the formation of a by-product could be observed (Fig. 1).

For the identification of the degradation by-product, two samples were chosen corresponding to reactions quenched at $10 \mathrm{~min}$ in the kinetic experiment. Degradation of alloxydim in 


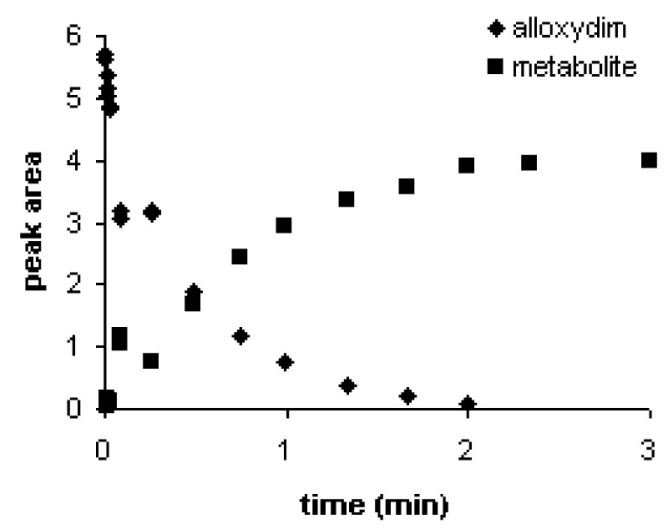

Figure 1. Degradation of alloxydim and formation of one of the main by-products at $\mathrm{pH}=9$ and $25 \pm 2{ }^{\circ} \mathrm{C}$.

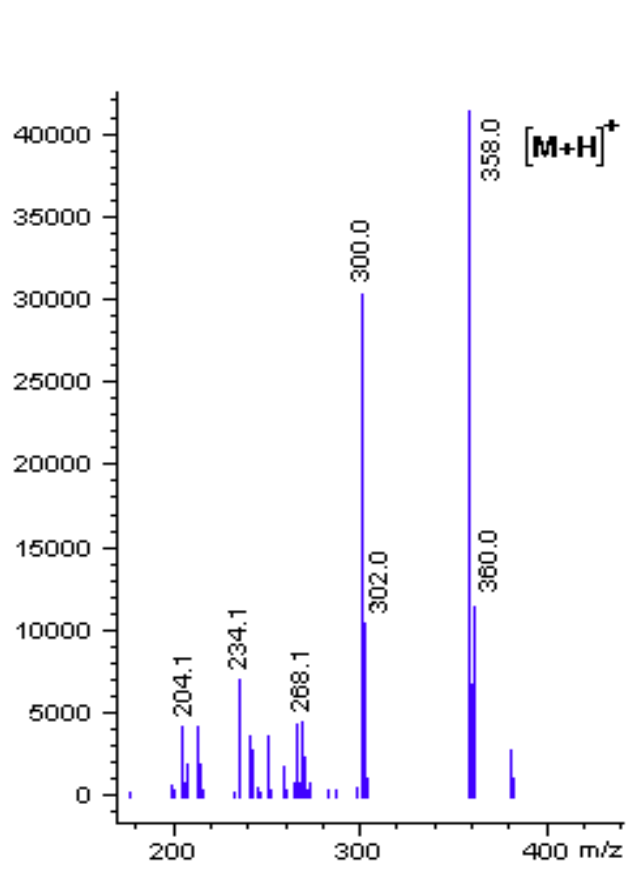

Figure 2. Electrospray mass spectra of chlorinated by-product of alloxydim.

hypochlorite-chlorinated water proceeds to yield a main reaction product with $\mathrm{m} / \mathrm{z}=358$ (Fig. 2). This corresponds to the molecular weight of alloxydim plus a chlorine atom. The isotopic distribution of the molecular ion agrees well with the theoretical distribution expected for a chlorinated derivative of alloxydim. However, with the information obtained from the mass spectrum it is not possible to determine its exact position within the molecule.

During the reaction, two more minority peaks with $\mathrm{m} / \mathrm{z}=322$ and 294 were detected, that disappeared after ten minutes of reaction. However, these products were characterized by a very scarce fragmentation and it is not possible to elucidate plausible structures.
Table I. Effects on root growth of alloxydim and main metabolite on wheat. Different letters show significant differences according to Newman-Keuls multiple range test $(P<0.05)$.

\begin{tabular}{lcc}
\hline $\begin{array}{l}\text { Dose } \\
(\mathrm{mg} / \mathrm{L})\end{array}$ & \multicolumn{2}{c}{$\begin{array}{c}\text { Root Growth 7 DAT } \\
(\mathrm{cm})\end{array}$} \\
\cline { 2 - 3 } & Alloxydim & Metabolite \\
\cline { 2 - 3 } & Mean & Mean \\
\hline 0 & $15.20 \mathrm{a}$ & $12.60 \mathrm{a}$ \\
0.1 & $13.67 \mathrm{a}$ & $13.15 \mathrm{a}$ \\
0.2 & $11.65 \mathrm{a}$ & $13.07 \mathrm{a}$ \\
0.3 & $9.04 \mathrm{~b}$ & $13.59 \mathrm{a}$ \\
0.4 & $4.93 \mathrm{c}$ & $13.30 \mathrm{a}$ \\
0.5 & $2.64 \mathrm{~d}$ & $13.35 \mathrm{a}$ \\
0.7 & $1.58 \mathrm{e}$ & $12.94 \mathrm{a}$ \\
1 & $0.90 \mathrm{e}$ & $12.23 \mathrm{a}$ \\
5 & & $12.60 \mathrm{a}$ \\
10 & & $8.55 \mathrm{~b}$
\end{tabular}

Therefore, degradation of alloxydim in chlorinated water gives rise to a main chlorinated by-product. This is an important feature with respect to the toxicological and ecotoxicological relevance of this metabolite and to possible confusing results in efficacy and phytotoxicity bioassays (Sandín-España et al., 2003).

For the isolation of the alloxydim by-product, the reaction between alloxydim and hypochlorite at a higher concentration than in the kinetic experiment was studied. The complete disappearance of alloxydim and the maximum concentration of metabolite occurred after approximately ten minutes. The reaction yield was $20 \%$. At this moment the reaction was stopped and passed through the cartridge. Different eluents and their volumes were tested to obtain the maximum recovery of the metabolite. The best conditions were found to be $2 \times 5 \mathrm{~mL}$ of $\mathrm{CH}_{2} \mathrm{Cl}_{2}$.

\subsection{Bioassays to determine phytotoxicity on wheat}

A bioassay was performed to compare the possible effect of alloxydim and metabolite on wheat at different doses of herbicide. The results presented in Table I, after seven days of treatment, show that the most sensitive biological parameter to alloxydim was root length, causing a $40 \%$ significant reduction in the root growth of plants at the dose of $0.3 \mathrm{mg} \cdot \mathrm{L}^{-1}$ and $94 \%$ reduction at the highest dose. However, the effect of metabolite on root growth only occurred at the highest metabolite dose, causing a $32 \%$ reduction in root growth.

The root system control presented normal growth (main tap root plus secondary roots), while those from injured plants were increasingly deformed (main tap root twisted and lack of secondary roots). Root growth was increasingly affected with doses from $0.1 \mathrm{mg} \cdot \mathrm{L}^{-1}$ to the highest dose. 
Further bioassays are necessary to compare the phytotoxicity of both substances.

\section{CONCLUSION}

The herbicide alloxydim rapidly reacts with sodium hypochlorite, forming a main chlorinated by-product observed in ultraviolet and mass spectrometry, which has not been detected before. Bioassays show that the metabolite has an effect on the root growth. Phytotoxicity of the metabolite seems to be lower than that showed by alloxydim. These results suggest that chlorine treatment of water containing this herbicide will result in significantly lower residues, but can also contain new compounds that should be considered for their potential health relevance. Studies to provide more detailed structural information of by-products are being performed in our laboratory.

Acknowledgements: This work was financed by grant RTA 01-034 from INIA. P.S.-E. was supported by an INIA predoctoral fellowship.

\section{REFERENCES}

Hernández-Sevillano E., Villarroya M., Alonso-Prados J.L., GarcíaBaudín J.M. (2001) Bioassay to detect sulfosulfuron and triasulfuron residues in soil, Weed Technol. 15, 447-452.
Hewitt E.J., Bould C. (1963) A treatise of plant physiology, Academic Press, New York, Vol. III, pp. 15-133.

Horowitz M. (1976) Application of bioassay techniques to herbicide investigations, Weed Res. 16, 209-215.

Hu J.Y., Aizawa T., Magara Y. (1999) Analysis of pesticides in water with liquid chromatography/atmospheric pressure chemical ionization mass spectrometry, Water Res. 33, 417-425.

Lichtenthaler H.K. (1990) Mode of action of herbicides affecting AcetylCoA carboxylase and fatty acid biosynthesis, Z. Naturforsh. 45, 521-528.

Magara Y., Aizawa T., Matumoyo N., Souna F. (1994) Degradation of pesticides by chlorination during water purification, Water. Sci. Technol. 30, 119-128.

Maier A., Golz A., Lichtenthaler H.K., Meyer N., Retzlaff G. (1994) Studies on the effect of different cyclohexane-1,3-diones on de-novo fatty acid biosynthesis in Poaceae, Pestic. Sci. 42, 153-161.

Reckhow D.A., Singer P.C. (1990) Chlorination by-products from drinking waters: from formation potential to finished water concentrations, J. Am. Water Works Assoc. 82, 173-180.

Sandín-España P., González-Blazquez J.J., Magrans J.O., García-Baudín J.M. (2002) Determination of herbicide tepraloxydim and main metabolites in drinking water by solid-phase extraction and liquid chromatography with UV detection, Chromatographia 55, 681686.

Sandín-España P., Llanos S., Magrans J.O., Alonso-Prados J.L., GarcíaBaudín J.M. (2003) Optimization of hydroponic bioassay for herbicide tepraloxydim by using water free from chlorine, Weed Res. $43,451-457$ 